probably not to be taken as indicating that the cells were of the squamous variety.

The course of the disease differs but little from that of sarcoma. It is said that bleeding is less frequent and that the lymph-glands begin to enlarge later, but in our case marked glandular enlargement was present at an early stage, and hæmorrhage, although never large in amount, has been a quite definite feature of the case. Mickulicz, in his articlein Heymann's "Handbuch"; states that while sarcoma tends to tumour-formation and obstructive symptoms, carcinoma is characterised by disintegration and early destruction of neighbouring structures. This distinction certainly appears to be applicable to a majority of the cases described, but in ours tumour-formation was considerable and nasal obstruction one of the first symptoms.

\title{
REFERENCES.
}

JACKson.--"Primary Carcinoma of Naso-pharynx; a Table of Cases," Journ. Amer. Med. Assoc., 1901, vol. xxvii, p. 371.

Eduen.-New York Med. Journ., March, 1901.

Laval, F.-“Tumeurs malignes du Naso-pharynx," A rch. Internat. de Laryngol., 1905, xix, pp. 55-75.

CoMPAIRED.- “Nouveau cas d'Epithéliome Naso-pharyngé avec invasion de toute la voute Palatine et des sinus Sphénoïdaux," Arch. Internat. de Laryngol.," 1907, p. 201.

\section{ON EVISCERATION OF THE TONSILS.}

By C. G. Russ Wood, F.R.C.S.Eng., L.R.C.P.Lond., Surgeon to the Eye, Ear and Throat Hospital, Shrewsbury.

During recent years enucleation of the tonsils has been extensively practised, and to a great extent has displaced the older operation of tonsillotomy, no doubt in many cases with advantage. But all new methods which are taken up with enthusiasm tend to overshadow older procedures, which sometimes thus fall into undeserved oblivion. When tonsillotomy has been performed, it is sometimes completed by breaking up the substance of the tonsil with the finger, and it is to this procedure, somewhat elaborated, that I wish to draw attention.

The drawbacks to enucleation of the tonsils are, the time occupied by the operation, necessitating either choroform or ether anæsthesia; the occurrence of severe hæmorrhage, which not infrequently takes place after the tonsil has been removed from its 
fossa ; and the length of time the patient has to stay in bed after the operation, which, in a hospital where the beds are limited, is an important matter. Its great advantage is the thoroughness of the removal of the diseased gland.

The operation to be described, which may be termed "evisceration," is, I think, the preferable procedure in the majority of cases. Among its advantages are, that it can be easily performed under nitrons oxide anæsthesia, and the small amount of hæmorrhage, so that risk of blood passing into the larynx is obviated; the bleeding is less than that which occurs after an ordinary tonsillotomy, and compared to that which takes place after enucleation, negligable. Also the patient can return home as soon as after the operation of tonsillotomy. It is especially applicable to that form of chronic tonsillitis which is entirely within the faucial pillars and does not project towards the middle line; at the same time the supratonsillar fossa is well opened and cleared out.

The procedure which I generally adopt is as follows: The patient lies supine on the table, and a Doyen's gag having been placed between the teeth, nitrous oxide anæsthesia is induced; when complete the gag is fully opened by an assistant, tonsillotomy is quickly performed, and the guillotine put aside. The surgeon's right thumb is now placed behind the angle of the jaw on the patient's right side and the forefinger of the same hand in the corresponding position on the left side. The finger and thumb thus grasp the neck just below the mandible, pressing both tonsils well inwards. The forefinger of the left hand is now passed into the mouth, and the tonsils are broken up in succession, beginning in the supra-tonsillar fossa and rapidly working downwards, firm counter-pressure meanwhile being made by the finger and thumb of the right hand. The glands easily come away as a thick grumous fluid. The patient is then quickly put into the sitting position and expectorates the broken-up tonsils into a bowl. It is quite unnecessary to remove a large piece of the tonsil with the guillotine, merely opening the capsule is sufficient. In children under eight years or so it is frequently not necessary to use the instrument at all, because the tonsil capsule can be easily ruptured by pressure of the finger. If there have been many attacks of torsillitis the glands are firm and too fibrous to permit evisceration to be carried out efficiently, and enucleation should be performed. But this is not invariably so, because some months ago I advised the removal of two very large tonsils in a young man of twentyfour; the right tonsil I enucleated, but the hæmorrhage was so 
profuse that I decided to eviscerate the left, in spite of knowing it was very fibrous in texture from repeated attacks of tonsillitis. This was carried out accordingly, and on seeing him two months later it was not possible to say on inspection which tonsil had been enucleated and which eviscerated.

I have carried out this method on over 700 patients and have never seen any ill-effects follow. Within twenty-four hours the tonsillar fossa is filled up with inflammatory exudation within the gland-capsule, but this entirely disappears in a week or so; at the same time there is no more post-operative odynphagia than after an ordinary tonsillotony.

Possibly immunity from unpleasant after-effects is in part due to a measure which I have for many years always carried out in connection with tonsil operation cases; it consists in giving calomel, gr. $\frac{1}{10}$, in a sugar pilule, and the patients are instructed to suck one every five minutes; these are given about two to three hours after the operation and repeated in the morning for the following three days. Children of six years are given about seven pilules, those of twelve or fourteen the same number as they are years old, and adults sixteen to eighteen. The calomel seems to have a local antiseptic action on the throat, and a remote one by opening the bowels to some extent. This method of administering calomel was advised by Dr. Dewar ${ }^{1}$ some years ago in acute tonsillitis and he suggested its use after these operations. Being made up with sugar children take them easily, and I find these pilules are far superior to formalin lozenges. The usual after-treatment of tonsillotomy is carried out as well, but there is no need to enter into these well-known details.

With regard to this method, the advantages are the ease with which it can be carried out under nitrous oxide anæsthesia, the freedom from troublesome hæmorrhage, and the effectual clearing out of the supra-tonsillar fossa. For these reasons I suggest evisceration as a procedure which is worthy of consideration in many of those patients whose tonsils are chronically enlarged and require operative interference.

\footnotetext{
1 Brit. Med. Journ., November, 1900.
} 